\title{
Pemanfaatan material fasa berubah untuk mempertahankan kesegaran sayuran
}

\author{
Muhammad Irsyad 1 ${ }^{*}$, Natal Andreas H. L. Tobing ${ }^{2}$, M. Dyan Susila ${ }^{3}$ \\ 1,2,3 Jurusan Teknik Mesin, Fakultas Teknik, Universitas Lampung \\ Jl. Prof. Soemantri Brojonegoro, No. 1, Kota Bandar Lampung, 35145, Indonesia \\ *Corresponding author: muhammad.irsyad@eng.unila.ac.id
}

\begin{abstract}
Indonesia is an agricultural country with a tropical climate. One of the many agricultural products in Indonesia is vegetables. Handling of vegetables after harvesting is important because the decrease in product quality can reach up to 50\%. This decrease in quality is the result of metabolic processes such as transpiration and respiration that occur in post-harvest vegetables. The respiration rate of vegetables cannot be stopped but can be slowed down by lowering the temperature, so that the freshness of the vegetables can last longer. One method of maintaining the temperature of vegetables is storage in a cool box with cooling media. Phase change material (PCM) is an alternative cooling medium that utilizes latent heat in thermal energy storage. Paraffin is a PCM that can be used for this application. Paraffin has a freezing and melting temperature range that can be adjusted according to your needs, namely by mixing liquid paraffin and solid paraffin. This study used mixed paraffin with a liquid-solid paraffin ratio of 98:2 mass basis. This mixture has a melting temperature of $6^{\circ} \mathrm{C}$ until $13^{\circ} \mathrm{C}$ and is close to the optimal temperature for storing vegetables, which is $5^{\circ} \mathrm{C}$. In this study, testing was also carried out using water as a comparison. The test results show that ice can make vegetables last longer in cold conditions, namely that it is able to maintain the vegetable temperature below $20^{\circ} \mathrm{C}$ for 11 hours, while paraffin only lasts 2 hours. The physical condition of the vegetables that are cooled with ice in the packing changes color and becomes watery because the water in the vegetables is condensed. Meanwhile, on cooling with paraffin it is physically fresher.
\end{abstract} Keywords: PCM, paraffin, cool box, fresh vegetable storage.

\begin{abstract}
Abstrak
Indonesia merupakan negara agraris yang beriklim tropis. Salah satu produk pertanian yang banyak di Indonesia adalah sayuran. Penanganan sayur setelah panen penting dilakukan karena penurunan kualits produk bisa mencapai 50\%. Penurunan mutu tersebut adalah akibat proses metabolisme seperti transpirasi dan respirasi yang terjadi pada sayuran setelah panen. Laju respirasi dari sayuran tidak dapat dihentikan namun dapat diperlambat dengan menurunkan temperaturnya, sehingga kesegaran sayuran dapat bertahan lebih lama. Salah satu metode mempertahankan temperatur sayuran adalah dengan penyimpanan di cool box yang diberi media pendingin. Material fasa berubah atau phase change material (PCM) merupakan alternatif media pendingin yang memanfaatkan panas laten dalam penyimpanan energi termal. Parafin merupakan salah satu PCM yang bisa dimanfaatkan untuk aplikasi ini. Parafin memiliki rentang temperatur beku dan leleh yang dapat disesuaikan dengan kebutuhan yakni dengan cara mencampur parafin cair dan parafin padat. Penelitian ini menggunakan parafin campuran dengan perbandingan parafin cair-padat adalah 98:2 basis massa. Campuran ini memiliki temperatur leleh dari $6^{\circ} \mathrm{C}$ sampai $13^{\circ} \mathrm{C}$ dan sudah mendekati suhu optimal penyimpanan sayuran yakni $5^{\circ} \mathrm{C}$. Dalam penelitian ini juga dilakukan pengujian menggunakan air sebagai pembanding. Hasil pengujian menunjukkan bahwa es dapat membuat sayuran bertahan lebih lama dalam keadaan dingin yakni mampu mempertahankan temperatur sayur di bawah $20^{\circ} \mathrm{C}$ selama 11 jam, sedangkan paraffin hanya mampu 2 jam.
\end{abstract}


Kondisi fisik sayur yang didinginkan dengan es dalam packing mengalami perubahan warna dan berair karena air dalam sayur terkondensasi. Sedangkan pada pendinginan dengan parafin secara fisik lebih segar.

Kata kunci : PCM, parafin, cool box, penyimpanan sayuran segar.

\section{Pendahuluan}

Indonesia adalah negara beriklim tropis yang memiliki sumber daya alam yang sangat melimpah. Posisi geografis negara Indonesia memungkinkan untuk menjadi tempat yang sangat baik untuk beragam jenis flora dan fauna. Iklim yang baik dan kondisi tanah yang subur menjadikan negara Indonesia menjadi salah satu negara penghasil hasil bumi terbesar di dunia. Produk hasil bumi yang cukup besar merupakan produk hasil pertanian meliputi buah-buahan dan sayuran.

Sayuran merupakan tumbuhtumbuhan yang dimanfaatkan sebagai bahan makanan. Sayur-sayuran berdasarkan bagian organ yang dimanfaatkan dapat dibedakan sebagai berikut: sayuran akar, sayuran bunga, sayuran batang, sayuran buah dan sayuran daun [1]. Sayuran daun merupakan sayuran yang banyak dikonsumsi masyarakat Indonesia karena sayuran daun sangat mudah didapatkan dan tidak sulit untuk diolah menjadi makanan. Beberapa jenis sayuran daun yaitu bayam, sawi, dan kangkung.

Sayuran daun termasuk sayuran yang sangat cepat mengalami kemunduran mutu atau kesegarannya. Berdasarkan penelitian yang telah dilakukan, penurunan mutu sayur-sayuran di negara berkembang dapat mencapai $40 \%$ sampai $50 \%$ [2,3]. Penurunan mutu sayur-sayuran ini disebabkan oleh adanya aktifitas metabolisme biologis pada daun dan batangnnya. Aktifitas biologis yang terjadi pada sayur-sayuran setelah panen yaitu proses respirasi dan transpirasi. Proses respirasi dan transpirasi ini tidak dapat dihentikan namun dapat dihambat dengan melakukan beberapa perlakuan pada sayuran setelah dipanen. Salah satu perlakuan yang dapat dilakukan adalah dengan cara pengondisian suhu sayuran segar [4].
Suhu merupakan faktor eksternal yang sangat berpengaruh pada proses respirasi dan transpirasi sayuran. Semakin tinggi suhu, maka semakin cepat pula proses respirasi dan transpirasi yang menyebabkan sayuran semakin cepat kehilangan kesegarannya. Oleh karena itu, dengan pengkondisian suhu maka proses metabolisme sayuran dapat diperlambat sehingga kesegaran sayur dapat bertahan lebih lama. Berdasarkan riset yang dilakukan, sayuran daun dan bunga seperti bayam, daun bawang, brokoli dan lain-lain, memiliki laju kerusakan yang tinggi sehingga hanya dapat disimpan sampai dua minggu pada temperatur rendah [5]. Penyimpanan sayuran gonda pada temperatur $7-10^{\circ} \mathrm{C}$ dapat bertahan selama 2,3 hari [6]. Pengkondisian suhu sayuran ini dapat dilakukan dengan menyimpan sayuran di dalam ruangan refrigerator sampai sayuran dijual. Penggunaan refrigerator ada yang statis untuk penyimpanan di tempat, dan refrigerator mobile untuk proses pengangkutan. Metode ini kurang cocok untuk para petani skala kecil. Ada metode yang memungkinkan dilakukan untuk petani skala kecil dalam menyimpan sayur adalah dalam box yang ditambahkan material untuk menyerap termal dari sayur dan rugi-rugi panas dari luar box. Material ini berfungsi sebagai penyimpan energi termal (themal energy storage disingkat TES). Material yang memanfaatkan panas laten dalam menyimpan energi termal adalah material berubah fasa (phase changes material disingkat PCM).

PCM merupakan material yang memanfaatkan perubahan fasa ketika menyerap (charging) dan melepaskan (discharging) kalor, namun struktur atau susunan kimianya itu tidak mengalami perubahan [7]. PCM yang biasa digunakan adalah air dalam bentuk es. PCM lain yang 
dapat digunakan dalam pendinginan adalah parafin. Parafin merupakan PCM organik yang didapatkan melalui proses destilasi minyak bumi [8]. Parafin memiliki sifat yang lebam (inert) dan stabil di bawah suhu $500^{\circ} \mathrm{C}$. Selain itu, parafin tidak mengalami perubahan volume yang signifikan ketika mencair dan memiliki tekanan uap yang relatif rendah ketika dalam bentuk cair [9]. Berdasarkan karakterisitik tersebut, maka sistem yang menggunakan parafin sebagai PCM biasanya mengalami siklus padat-cair yang panjang [10].

Dengan sifat parafin yang sangat baik dalam menyimpan panas, maka parafin dapat membantu mempertahankan temperatur cool box dalam penyimpanan sayuran segar. Temperatur cool box yang rendah, dapat dikondisikan oleh parafin akan menghambat laju respirasi dan transpirasi pada sayuran sehingga sayuran dapat dipertahankan kesegarannya dalam jangka waktu yang lebih lama. Dengan kebutuhan temperatur pendinginan sayuran yang mencapai $5^{\circ} \mathrm{C}$, jenis parafin yang paling tepat adalah parafin dengan jumlah atom karbon 14 atau C-14. Parafin C-14 memiliki melting point atau titik leleh pada temperatur $6,02^{\circ} \mathrm{C}$, sehingga dapat memanfaatkan panas laten dalam menyerap energi termal [11]. Parafin C-14 masih sulit ditemukan di pasaran dibandingkan dengan parafin cair dan parafin padat. Oleh karena itu, alternatif yang dapat dilakukan adalah memadukan parafin cair dan parafin padat dengan metode pemanasan untuk mendapatkan titik leleh yang diinginkan sebagai media pendinginan sayuran segar.

Penelitian ini bertujuan untuk mengetahui pengaruh penggunaan PCM dari parafin dan es dalam cool box untuk menjaga kesegaran sayuran

\section{Metode Penelitian}

Penelitian ini dimulai dari mencari komposisi campuran paraffin antara paraffin padat dan paraffin cair untuk memperoleh temperatur perubahan fasa yang sesuai dengan temperatur pendinginan, pengujian temperatur ruangan box tanpa beban, pengujian penurunan temperatur sayur dan pengujian mempertahankan temperatur sayur.

\section{Pengujian paduan parafin cair- padat}

Untuk memperoleh komposisi campuran paraffin yang sesuai, dilakukan pengujian temperatur perubahan fasa pada tiga macam variasi komposisi. Ketiga variasi komposisi paduan parafin cair dan parafin padat adalah sebagai berikut: 99:1, 98:2, dan 97:3. Setiap paduan bermassa total 100 gram. Pencampuran kedua jenis PCM ini adalah dengan cara memanaskan sampai temperatur $70^{\circ} \mathrm{C}$. Setelah paraffin bercampur dengan baik, specimen dimasukan dalam freezer dan didinginkan hingga temperatur $0^{\circ} \mathrm{C}$. Temperatur paraffin diukur menggunakan temrmokopel jenis $\mathrm{K}$ dan datalogger temperatur merek Lutron BTM-4208SD. Temperatur direkam setiap menit. Secara berkala proses pembekuanya dilihat mulai dari awal pembekuan sampai akhir pembekuan. Setelah proses pembekuan selesai, setiap paduan parafin cair-padat dikeluarkan dari freezer dan dibiarkan pada temperatur ruangan. Selama proses pelelehan, perubahan temperatur dari parafin akan diukur dan direkam pada temperatur recorder hingga mencapai temperatur lingkungan. Proses pelelehan diamati secara visual.

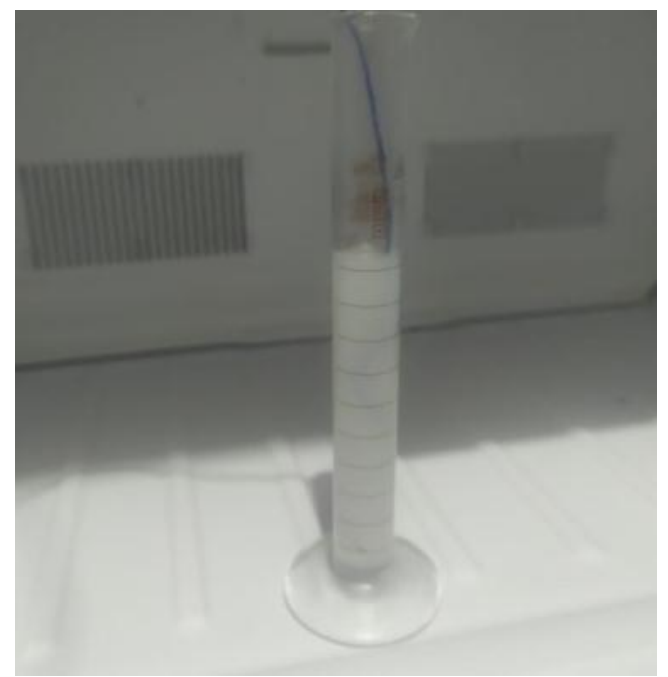

Gambar 1. Pengujian proses pembekuan parafin 


\section{Pengujian tanpa beban}

Pengujian ini dilakukan cool box kosong tanpa sayut. PCM parafin dan es yang telah didinginkan hingga mencapai temperatur kurang dari $0^{\circ} \mathrm{C}$ di dalam freezer dengan massa masing-masing $1 \mathrm{~kg}$, dimasukkan ke dalam cool box kosong secara bergantian. Posisi botol ice pack disandarkan pada keempat sisi dinding cool box seperti pada Gambar 2. Selama proses pengujian, perubahan temperatur diukur dan direkam pada temperatur recorder. Titik-titik sensor termokopel terdapat pada dua buah botol ice pack, satu buah tepat di tengah-tengah ruang cool box, dan 1 buah di luar cool box untuk mengukur temperatur lingkungannya.

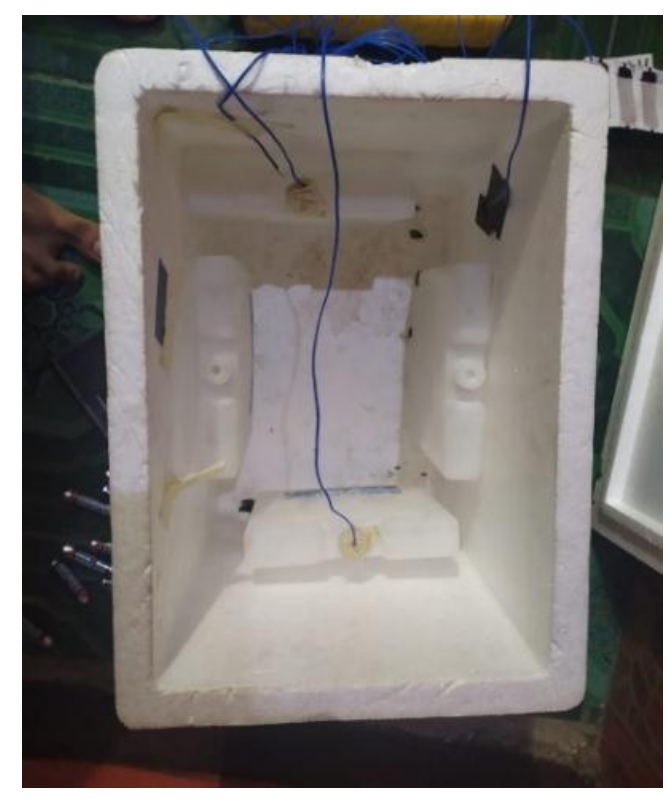

Gambar 2. Pengujian tanpa beban

\section{Pengujian menurunkan temperatur sayuran}

Pengujian ini dilakukan dengan memasukkan sayuran segar bertemperatur lingkungan ke dalam cool box yang telah berisi PCM dan sudah didinginkan mencapai temperatur $0^{\circ} \mathrm{C}$ dengan massa total $1 \mathrm{~kg}$. Sayuran dengan massa 750 gram dimasukkan ke dalam cool box. Posisi sayuran dikondisikan dengan bersilangan untuk menyesuaikan ukuran cool box, dan semua ice pack bersentuhan langsung dengan sayuran. Posisi ice pack dan sayuran ditunjukkan oleh Gambar 3.
Selama pengujian, perubahan temperatur diukur dan direkam menggunakan temperature recorder.

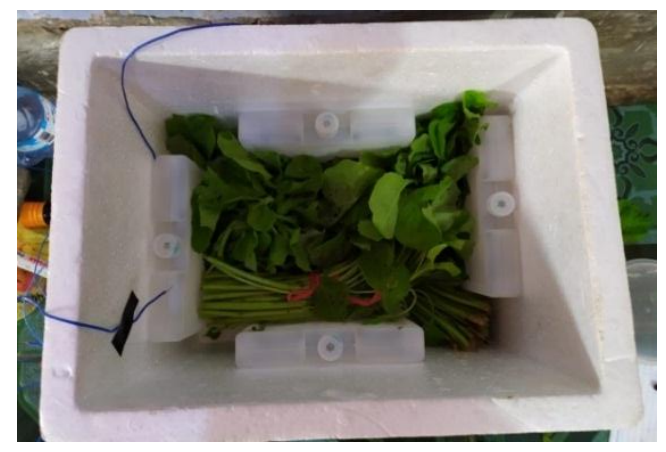

Gambar 3. Pengujian menggunakan sayuran

\section{Pengujian mempertahankan temperatur sayuran}

Pengujian ini dilakukan dengan mendinginkan terlebih dahulu sayuran segar dengan massa 750 gram hingga mencapai temperatur $5^{\circ} \mathrm{C}$. Sayuran tersebut kemudian dimasukkan ke dalam cool box setelah PCM disusun di dalamnya. Posisi sayuran di dalam cool box, dikondisikan berlawanan arah untuk menyesuaikan dengan ukuran cool box, dan semua ice pack bersentuhan langsung dengan sayuran, seperti diperlihatkan pada Gambar 3. Selama proses pengujian, perubahan temperatur diukur dan direkam pada temperature recorder.

\section{Hasil dan Pembahasan}

\section{Hasil pengujian paduan parafin cair- padat}

Proses pendinginan dilakukan di dalam lemari pendingin (freezer) sampai terjadi pembekuan pada PCM. Berdasarkan perubahan temperatur yang yang secara priodik dicatat, maka dapat diperoleh grafik perubahan temperatur yang terjadi selama proses pembekuan, seperti ditunjukkan pada Gambar 4. Secara visual diperoleh temperatur awal dan akhir pembekuan untuk masing-masing komposisi parafin. 


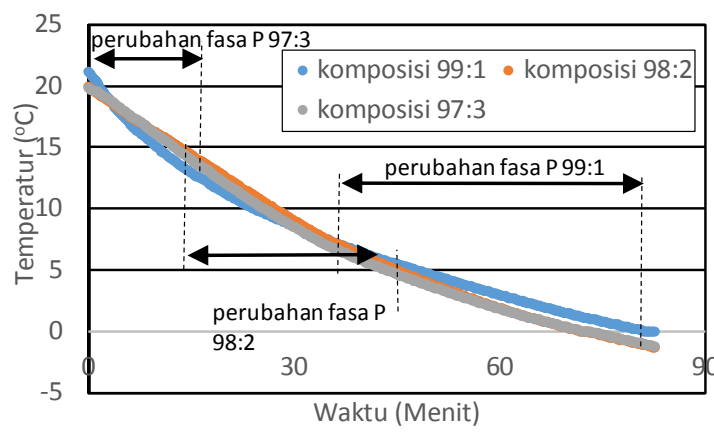

Gambar 4. Grafik temperatur parafin pada proses pembekuan

Proses pelelehan dilakukan di ruang terbuka pada temperatur lingkungan yakni $28^{\circ} \mathrm{C}$ dengan proses perpindahan panas konveksi alami. Setiap paduan parafin diukur perubahan temperaturnya secara priodik. Dari data tersebut diperoleh grafik hubungan antara temperatur PCM dan waktu, seperti pada Gambar 5. Pada saat proses pemanasan PCM ini secara visual diperoleh temperatur awal dan akhir pelelelehan.

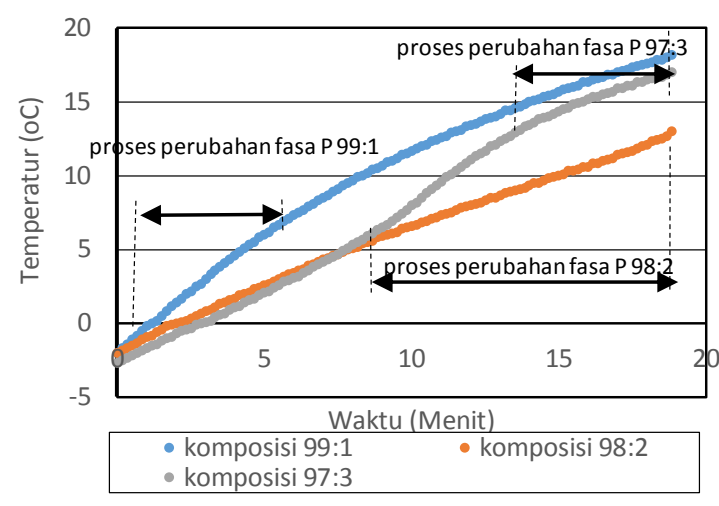

Gambar 5. Grafik temperatur paraffin pada proses pelelehan

Berdasarkan hasil pengujian proses pembekuan dan pelelehan maka dapat disimpulkan bahwa paduan yang paling layak untuk digunakan untuk penyimpanan sayur bayam adalah paduan parafin dengan komposisi cair dan padat adalah 98:2. Paduan tersebut mengalami perubahan fasa pada temperatur $6{ }^{\circ} \mathrm{C}$ sampai $13{ }^{\circ} \mathrm{C}$. Data temperatur perubahan fasa untuk masingmasing komposisi paraffin, diperlihatkan pada Tabel 1.
Tabel 1. Temperatur perubahan fasa parafin

\begin{tabular}{ccc}
\hline $\begin{array}{c}\text { Komposisi } \\
\text { paduan } \\
\text { (Cair:padat) }\end{array}$ & $\begin{array}{c}\text { Proses } \\
\text { pembekuan } \\
\left({ }^{\circ} \mathrm{C}\right)\end{array}$ & $\begin{array}{c}\text { Proses } \\
\text { pelelehan } \\
\left({ }^{\circ} \mathrm{C}\right)\end{array}$ \\
\hline $99: 1$ & 7 s.d. -1 & -1 s.d 7 \\
\hline $98: 2$ & 15 s.d. 6 & 6 s.d 13 \\
\hline $97: 3$ & 22 s.d. 14 & 14 s.d 17 \\
\hline
\end{tabular}

\section{Hasil pengujian PCM tanpa beban}

Pada Gambar 5, terlihat bahwa

PCM es mampu mempertahankan temperatur ruangan box selama 10 jam yakni berkisar antara $16^{\circ} \mathrm{C}-17^{\circ} \mathrm{C}$. Hal ini disebabkan karena energi yang dapat diserap oleh es dengan memanfaatkan panas laten mencukupi, walaupun perbedaan temperatur antara temperatur es dan ruangan sangat sigfnifikan yang mengakibatkan laju perpindahan panas tinggi. Bersamaan dengan proses ini, es mengalami perubahan fasa sampai mencair semua. Setelah terjadi perubahan fasa es, kenaikan temperaur ruangan dan es cukup signifikan, karena penyerapan panas pada air hanya mengandalkan panas sensibel.

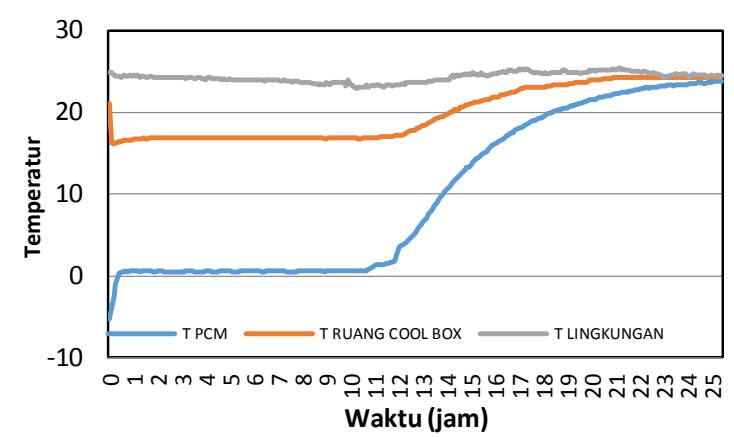

Gambar 5. Grafik perubahan temperatur pada pengujisn PCM es selama pengujian tanpa beban

Grafik hasil pengujian penggunaan PCM parafin untuk cooling box kosong diperlihatkan pada Gambar 6. Temperatur udara di dalam cool box mengalami penurunan hingga mendekati temperatur $16^{\circ} \mathrm{C}$, namun 1,5 jam kemudian sudah naik menjadi $20^{\circ} \mathrm{C}$. Ini menunjukkan penyimpanan energi termal parafin jauh lebih sedikit dibandingkan dengan es. Peningkatan temperatur parafin juga terlihat lebih cepat. Tidak terdapat grafik yang landai pada saat temperatur paraffin 
naik walaupun melewati proses perubahan fasa. Proses perubahan fasa tidak terlihat dari grafiknya karena range perubahan fasanya sangat lebar.

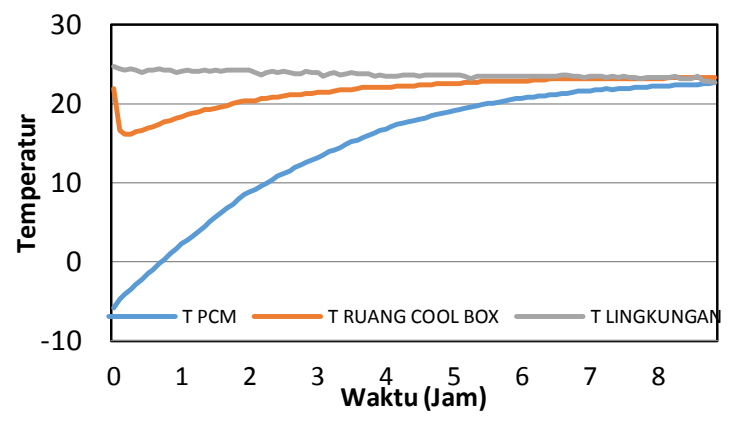

Gambar 6. Grafik perubahan temperatur pada pengujian PCM parafin tanpa beban

\section{Hasil pengujian menurunkan temperatur sayuran}

Sayuran segar mampu didinginkan hingga mencapai temperatur $11^{\circ} \mathrm{C}$ dengan menggunakan PCM es, seperti diperlihatkan pada Gambar 7. Penurunan temperatur sayur ini terjadi akibat terjadinya perpindahan panas dari sayur ke es, sedangkan pada es dengan bertambahnya energi termal maka terjadi perubahan fasa menjadi cair dan peningkatan temperatur.

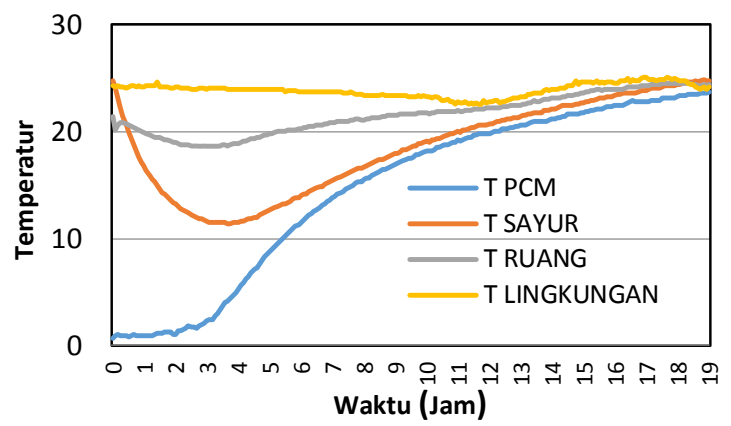

Gambar 7. Grafik perubahan temperatur pada pengujian PCM es untuk menurunkan temperatur bayam

Temperatur sayuran dan cool box mengalami peningkatan setelah 3 jam pertama. Hal ini disebabkan kaena es sudah mencair sehingga hanya menggunakan panas sensibel dalam menyerap panas sayur. Kondisi ini mengakibatkan peningkatan temperatur air lebih cepat dan temperatur sayuran juga turut meningkat. Penggunaan es dapat mempertahankan temperatur sayuran di bawah $20^{\circ} \mathrm{C}$ selama 11 jam.

Pada Gambar 8, dapat dilihat bahwa penggunaan PCM paraffin dapat menurunkan temperatur sayuran hingga mendekati $15^{\circ} \mathrm{C}$ dan kemudian berangsur naik kembali. Peningkatan temperatur sayuran setelah mencapai titik minimum disebabkan karena ada energi termal yang masuk dari lingkungan ke dalam cooling box secara kontinyu. Sementara itu PCM parafin tidak mampu menyerap keseluruhan energi tersebut sehingga sayuran yang temperaturnya juga rendah ikut menyerap energi termal tersebut sehingga temperaturnya juga berangsur meningkat. Temperatur sayur dapat dipertahankan di bawah $20^{\circ} \mathrm{C}$ selama 5 jam. Kapasitas penyimpanan termal paraffin yang jauh lebih kecil dibandingkan air mengakibatkan waktu penggunaannya relatif lebih pendek.

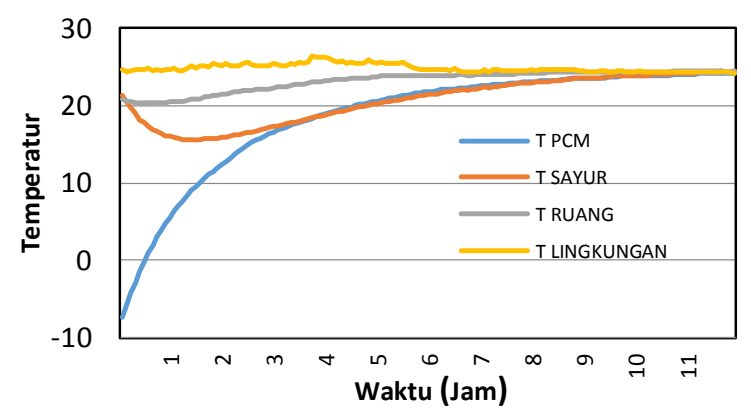

Gambar 8. Grafik perubahan temperatur pada pengujian PCM parafin untuk menurunkan temperatur bayam

Perbandingan penurunan temperatur sayuran akibat penggunaan es dan parafin dapat dilihat pada Gambar 9. Sayuran yang dimasukkan ke dalam cool box dengan es, dapat bertahan lebih lama dalam temperatur rendah dibandingkan dengan yang dimasukkan ke dalam cool box dengan parafin. Hal ini disebabkan karena sifat air yang dapat menyerap panas yang lebih besar dibandingkan parafin. Panas laten yang dimiliki air saat terjadi perubahan fasa dari padat menjadi cair adalah 334,72 $\mathrm{kJ} / \mathrm{kg}$, dimana nilai tersebut jauh lebih besar dibandingkan dengan parafin yang mendekati dengan temperatur perubahan 
fasa campuran paraffin ini yakni C14 dengan energi latennya $113,5 \mathrm{~kJ} / \mathrm{kg}$ [11].

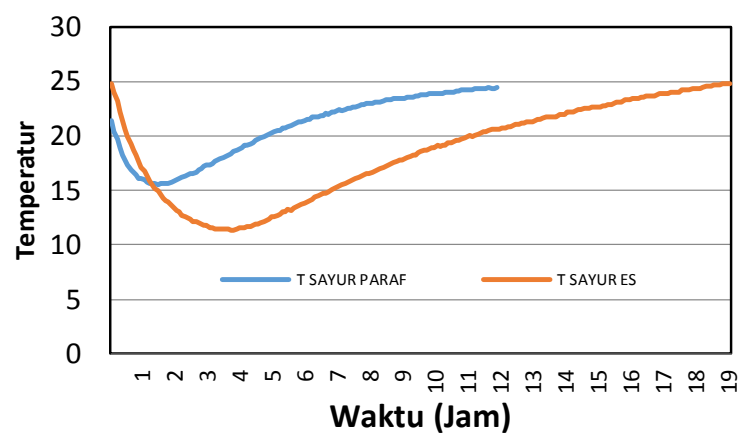

Gambar 9. Grafik perbandingan temperatur sayuran pada pengujian menurunkan temperatur

Sayuran segar setelah diuji dalam cool box untuk penggunaan PCM dari es maupun parafin masih tetap segar yang diperlihatkan oleh warna hijau yang terang, seperti diperlihatkan pada Gambar 10. Selain itu semua daunnya terlihat sehat dan dalam kondisi yang baik. Namun pada penggunaan es, sebagian daunnya terlihat berubah warna coklat kehitaman. Terutama daun-daun yang bersentuhan langsung dengan botol es. Hal ini disebabakan karena daun bayam yang bersentuhan dengan packing es mengeluarkan air dalam daunnya sehingga basah dan mengakibatkan daunnya lembek. Pada suhu yang terlalu rendah, sayuran akan mengalami kerusakan yang disebut chilling injury.



(a)

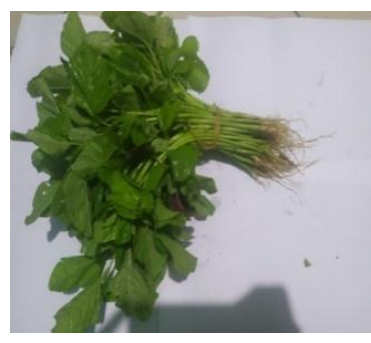

(b)
Gambar 10. Sayuran setelah pengujian menurunkan temperatur : (a) dengan PCM parafin, (b) dengan PCM es

\section{Hasil pengujian mempertahankan temperatur sayuran}

Pada pengujian mempertahankan temperatur sayuran menggunakan PCM es, terjadi peningkatan temperatur sayuran secara berlahan sampai temperatur $12^{\circ} \mathrm{C}$, kemudian bertahan pada temperatur ini selama 7 jam. Peningkatan temperatur sayuran di awal penyimpanan karena energi termal dari udara ruangan, dinding box serta dari lingkungan diserap oleh sayuran bersama PCM. Pada Gambar 11, terlihat bahwa temperatur sayuran mengalami peningkatan selama proses pengujian. Setelah lima jam pengujian, temperatur sayuran dan ruang cool box relatif konstan sampai jam ke 14. Sedangkan temperatur es relatif konstan pada $0^{\circ} \mathrm{C}$ sejak 30 menit awal pengujian sampai $11^{\circ} \mathrm{C}$. Pada proses ini es menyerap energi termal dengan menggunakan panas laten sampai terjadi perubahan fasa menjadi cair semuanya. Pemanfaatan panas laten dari es dalam menyerap energi termal mampu mendinginkan ruangan di dalam cool box dan sayur mencapai temperatur sekitar $16^{\circ} \mathrm{C}$ dan temperatur $12^{\circ} \mathrm{C}$.

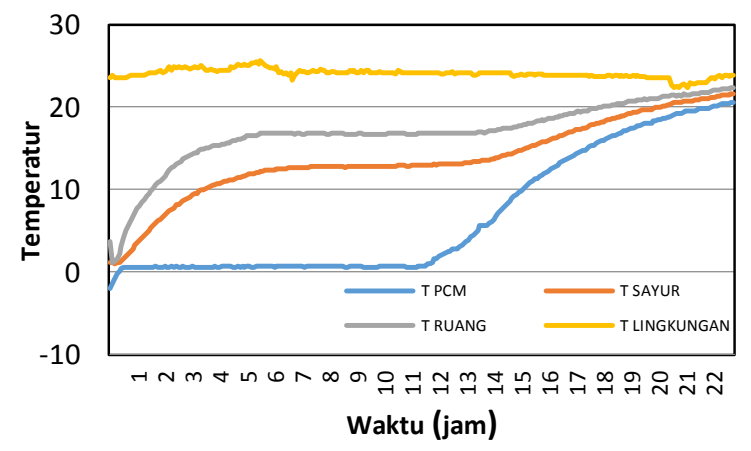

Gambar 11. Grafik perubahan temperatur pada pengujian PCM es untuk mempertahankan temperatur bayam

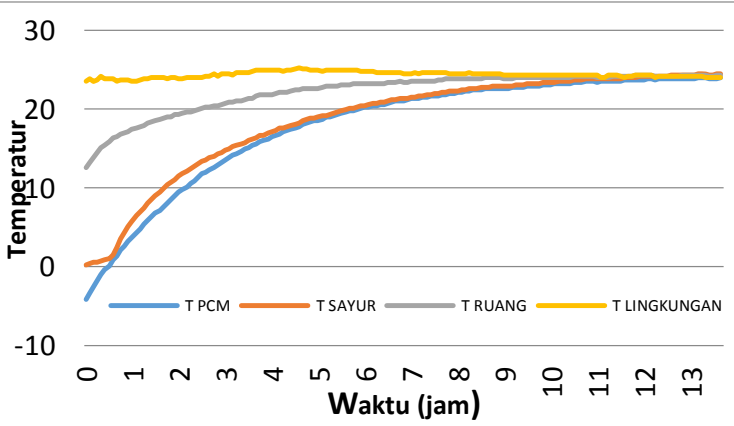

Gambar 12. Grafik perubahan temperatur pada pengujian PCM es untuk mempertahankan temperatur bayam

Pada Gambar 12 terlihat perubahan temperatur dari sayuran, ruang cool box 
maupun parafin. Temperatur sayur dan PCM dan ruang secara bersamaan mengalami kenaikan setiap perubahan waktu. Berbeda dengan es, parafin terus mengalami kenaikan temperatur seiring bertambahnya waktu karena perubahan fasa terjadi dalam range temperatur yang lebar. Seiring dengan kenaikan temperatur, laju perpindahan panas juga mengalami penurunan. Hal ini disebabkan karena perbedaan temperatur PCM dan lingkungan semakin kecil. Temperatur sayuran dapat dipertahankan sampai temperatur $20^{\circ} \mathrm{C}$ selama 6 jam. Hal yang sama juga dialami PCM. Dari hasil ini memperlihatkan bahwa penggunaan paraffin hanya untuk waktu yang pendek.

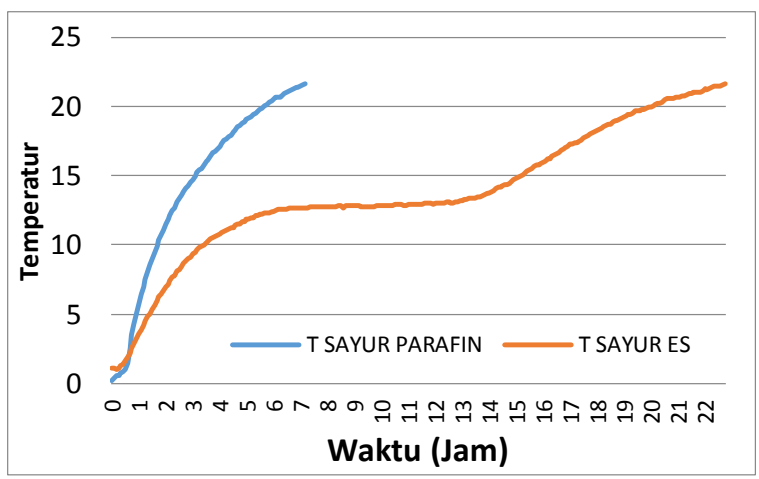

Gambar 13. Grafik perbandingan temperatur sayuran pada pengujian mempertahankan temperatur

Berdasarkan grafik pada Gambar 13, terlihat bahwa sayuran yang dimasukkan ke dalam cool box dengan es, dapat bertahan lebih lama dalam temperatur rendah dibandingkan dengan yang dimasukkan ke dalam cool box dengan parafin. Hal ini disebabkan karena sifat air yang dapat menyerap panas yang lebih besar dibandingkan parafin.

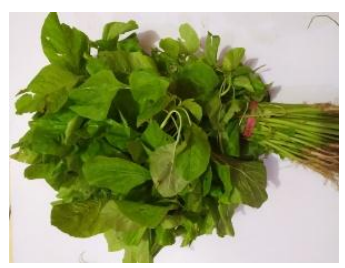

(a)

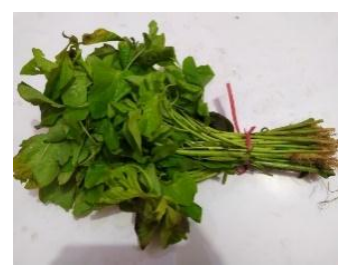

(b)
Gambar 14. Sayuran setelah pengujian mempertahankan temperatur: (a)dengan PCM parafin, (b) dengan PCM es
Visualisasi sayuran bayam setelah dilakukan pengujian mempertahankan temperatur diperlihatkan pada Gambar 14. Sayuran segar yang telah dimasukkan ke dalam cool box dengan parafin terlihat tetap hijau terang yang segar dan cukup mengkilap pada daun-daunnya. Sementara itu, sayuran yang dimasukkan ke dalam cool box dengan media pendingin es juga terlihat segar. Bahkan setiap daunnya juga terlihat hijau dan lebih merngkilap karena lebih berair. Namun, seperti halnya pada pengujian sebelumnya, sebagian daun yang kontak langsung dengan botol es mengalami perubahan warna coklat kehitaman. Perubahan warna tersebut merupakan indikasi terjadi kerusakan pada daun akibat suhu yang terlalu rendah.

\section{Kesimpulan}

Komposisi paduan parafin cairpadat yang terbaik untuk mempertahankan kesegaran sayuran adalah 98:2. Parafin dengan paduan tersebut memiliki titik leleh (melting point) pada temperatur $6-13^{\circ} \mathrm{C}$, dan terus mengalami perubahan fasa dari pada hingga mencair sampai temperatur 14 ${ }^{\circ} \mathrm{C}$. Titik leleh parafin dengan paduan cairpadat 98:2 sangat mendekati temperatur optimal penyimpanan sayuran daun segar khususnya bayam yaitu pada temperatur 5 ${ }^{\circ} \mathrm{C}$. Penggunaan PCM es mampu mempertahankan temperatur sayur di bawah $20^{\circ} \mathrm{C}$ selama 11 jam, sedangkan paraffin hanya mampu 2 jam. Kondisi fisik sayur yang didinginkan dengan es dalam packing mengalami perubahan warna dan berair karena air dalam sayur terkondensasi. Sedangkan pada pendinginan dengan parafin secara fisik lebih segar.

\section{Referensi}

[1] Handayani, Widuri. 2015. Penanganan Segar Hortikultura Untuk Penyimpanan Dan Pemasaran. Prenamedia Group: Jakarta

[2] Kader, A. A. 2013. Postharvest Technology of Horticultural Crops - 
An Overview from Farm to Fork, Ethiop .J. Appl. Sci. Technol. (Special Issue No.1): 1- 8 (2013)

[3] Waryat dan Handayani Y, 2020, Implementasi Jenis Kemasan Untuk Memperpanjang Umur Simpan Sayuran Pakcoy , Jurnal Ilmiah Respati, Vol. 11, No.1, Hal. 33-45

[4] Amrat lal Basediya, A.L., Samuel, D.V.K., Beera, V., 2013, Evaporative cooling system for storage of fruitsand vegetables - a review, Journal of Food Science andTechnology, 50(3):429-442

[5] Kader, A.A., (1993) Postharvest handling. In: Preece JE, Read PE (eds) The biology of horticulture- an introductory textbook. John Wiley \& Sons, New York, pp 353-377.

[6] Tampubolon M., Sukewijaya I.M., Gunadi, I.G.A., 2017, Pengaruh precooling dan Suhu Simpan terhadap Kualitas Pascapanen Tanaman Gonda (Sphenoclea zeylanica Gaertn), EJurnal Agroekoteknologi Tropika, Vol.6., No.2, 194-205

[7] Wiwik Pudjiastuti, W., Hendartini, Supeni, G., dan Listyarini, A., 2011, Penelitian menggunakan cold roll box (CRB) dengan phase change materials (PCMs) untk mempertahankan kesegaran produk pertanian, J. Kimia Kemasan, Vol.33, No.2, 179-182.

[8] Akgun M, Aydin O, Kaygusuz. 2007. "Experimental study on melting/ solidification characteristics of a paraffin as PCM". Energy Conversion and Management 48(2):669-678

[9] Alkan, C., Kaya, K. \& Sarı, A., 2009, Preparation, Thermal Properties and Thermal Reliability of Form-Stable Paraffin/Polypropylene Composite for Thermal Energy Storage. J Polym Environ 17, 254

[10] Wang, Q., Zhou, D., Chen, Y., Eames, P., Wu, Z., 2020, Characterization and effects of thermal cycling on the properties of paraffin/expanded graphite composites, Renewable Energy Vol. 147 (1), 1131-1138

[11] Peng, H., Zhang, D., Ling, X., Li, Y., Wang, Y., Yu, Q., She, X., Li, X., and Ding, Y., 2018, n-Alkanes Phase Change Materials and Their Microencapsulation for Thermal Energy Storage: A Critical Review, Energy Fuels, 32, 7262-7293 